\title{
First observations of deep-sea coral reefs along the Angola margin
}

\author{
E. Le Guilloux ${ }^{a,{ }^{*}}$, K. Olu ${ }^{a}$, J.F. Bourillet ${ }^{b}$, B. Savoye ${ }^{b}$, S.P. Iglésias ${ }^{c}$ and M. Sibuet ${ }^{a}$ \\ a IFREMER, Département Etude des Ecosystèmes Profonds, Laboratoire Environnement Profond, Centre de \\ Brest, BP 70, 29280 Plouzané, France \\ ${ }^{\mathrm{b}}$ IFREMER, Département Géosciences Marines, Centre de Brest, 29280 Plouzané, France \\ c Museum National d'Histoire Naturelle, UMR 5178, Station de Biologie Marine, Département Milieux et \\ Peuplements Aquatiques, Place de la Croix, BP 225, 29182 Concarneau Cedex, France \\ *: Corresponding author : Le Guilloux E., Tel.: +33 298224 131; fax: +33 298224 757, email address : \\ erwan.le.guilloux@ifremer.fr
}

\begin{abstract}
:
The West African continental slope is an important theatre for geological survey prospecting and drilling for hydrocarbons but little is known about local deep-sea biological communities at these depths. While shallow-water reefs are common and well-known features in the tropics, only few records of deep-water corals exist at low latitudes, and most of them have been reported by historical oceanographic cruises undertaking circum-navigations of the world. This study, based on a multidisciplinary approach, presents a description of newly discovered deep-water coral reef communities along the Angola margin. Data from ROV, multibeam bathymetry, side-scan sonar and seismics from a deep-towed acoustic system (SAR) were used to describe the morphology of the coral mounds and their relationship with the local geological setting. The reef-building scleractinian coral Lophelia pertusa has colonised carbonate mounds that reach heights of ca. $30 \mathrm{~m}$ and follow an orientation that is correlated with salt tectonic processes. Recent erosion is suggested as a process that influences the shape of the mounds. Sixteen fish taxa were identified during the ROV video surveys, with some of them likely to have a strong affinity with dense-living corals. The species observed belong to families commonly associated with deep-water corals (i.e. Sebastidae, Berycidae, Lophiidae and Chaunacidae), except an abundant species belonging to the family Zoarcidae, rarely observed in this type of environment. Lucinidae shells were found around mounds. As this bivalve family is indicative of reduced sediment and generally associated with cold-seep environments, this finding could revive the debate over the relationship between the distribution of cold-water coral habitat and gas seeps. However, there is no present-day nutritional relationship between living coral and chemosynthetic-derived biomass. The possible role of fluid expulsion in carbonate precipitation acting as the first step for coral colonisation is nevertheless discussed.
\end{abstract}

Keywords: Angola margin; Deep-sea corals; Lophelia pertusa; ROV; Habitat mapping; Lucinids 


\section{Introduction}

Deep-sea or cold-water corals form an exceptional habitat along many continental slopes and are receiving increasing attention worldwide (Freiwald et al., 2004). Over the last decade, the biodiversity inventoried in temperate deep-water coral reefs has been deemed to be almost as high as the biodiversity in shallow, tropical coral reefs (Jensen and Frederiksen, 1992). However, equivalent diversity is not reflected in all groups of animals (Rogers, 1999). For instance, fish diversity is likely to be lower in cold-water coral reef habitats compared to their tropical counterparts. The majority of deep-sea coral records come from the North Atlantic Ocean, partly because of sampling bias resulting from past and ongoing deep-sea research close to the waters of developed countries using advanced technology such as manned submersibles and ROVs. At lower latitudes, while shallow-water reefs have been extensively studied, only few records of deep-water corals exist. Most of these records have been reported from historical oceanographic cruises circumnavigating the world (Challenger, Galathea, Valdivia, Talisman) (Zibrowius, 1980). Little is known about the deep-sea communities in these regions, but prospecting by oil companies and national programs evaluating biological resources, for example off Brazil, have recently provided consistent faunal lists and accessible geophysical data useful for the identification of deep-sea coral hotspots for the South Atlantic Ocean (Kitahara, 2007; Passeri Lavrado, 2006; Pires, 2007; Sumida et al., 2004). A specimen of Lophelia pertusa has also been dredged on the Walvis ridge off Namibia (Zibrowius and Gili, 1990). In the Gulf of Guinea, the presence of the reefbuilding coral $L$. pertusa was first reported close to the Congo canyon at a depth of $380 \mathrm{~m}$ during the 1950 Galathea cruise (Zibrowius, 1980).

The Gulf of Guinea is now an important theatre for geological surveys dedicated to prospecting and drilling for oil and gas and exploration which is now reaching the deep-sea environment. First samples of L.pertusa that were obtained from prospecting conducted in 1996 by the French oil company Total motivated scientific ROV deployment on the base of the detailed bathymetric map provided. L. pertusa was then observed in situ via ROV dives along a mound alignment that was revealed by geophysical data acquired during the ZAIANGO collaborative programme between Total and IFREMER (Savoye et al., 2000). The main objective of the sister project BIOZAIRE was to establish a reference state of the deep benthic communities along the Angola margin (Sibuet et al., 2002).

This paper presents results of the geophysical surveys (multibeam bathymetry, side-scan sonar and high-resolution seismics) and ROV dives that revealed the occurrence of large bioherms built by $L$. pertusa and associated megafauna. This is the first study to reveal the particular geological setting and biodiversity of this new deep-sea coral site. Geological setting and biological observations are used to discuss co-occurrence of cold seeps and cold-water corals, as previously suggested for Norwegian or NE Atlantic reefs and carbonate mounds (Henriet et al., 1998; Hovland et al., 1998)

\section{Material and methods}

\subsection{Study area}

The study site ZB is located on the outer continental shelf south of the Angola margin at about $400 \mathrm{~m}$ deep (Fig.1a). The slope is generally gentle $\left(\leq 1^{\circ}\right)$ and is adjacent to a highly productive upwelling zone (van Bennekom and Berger, 1984). Overall, annual primary productivity in surface waters along the western African coast is estimated to be over $200 \mathrm{~g} \mathrm{C} \mathrm{m}^{-2} \mathrm{yr}^{-1}$ (Antoine et al., 1996; Behrenfeld and Falkowski, 1997). The salt tectonic process, by which large deposits of salt are stretched along the Angola margin resulting from gravity and sediment loading, has been described previously (Brun and Fort, 2004; Duval et 
al., 1992). On the near Congo-Cabinda basin, gravitational processes created two structural domains each about $100 \mathrm{~km}$ wide: an extensional domain on the upslope and a compressive domain located on the downslope. The extensional domain (up to $1500 \mathrm{~m}$ deep) is locally characterised by a high degree of extension across listric faults creating individual rafts (Rouby et al., 2002). Deep-sea hydrocarbon reservoirs are currently exploited in the area. Previous geophysical surveys from the ZAIANGO programme were conducted by IFREMER on the Angola margin to explore the geological environment of the area (Savoye et al., 2000).

\subsection{Geophysical survey}

The geophysical data used in this study include bathymetric data from a SIMRAD EM12 multibeam echosounder and from the IFREMER deep-towed acoustic system (SAR) including a side-scan sonar at $180 \mathrm{kHz}$ and a deep-towed high-resolution seismic with a sparker source of 600-1 $700 \mathrm{~Hz}$ (Nouzé et al., 1997). The SAR survey was carried out $100 \mathrm{~m}$ above the bottom at depths ranging from 370 to $475 \mathrm{~m}$, and the mosaic obtained covers more than $22 \mathrm{~km}^{2}$ (Fig.1b). Echoes above the bottom were visible on seismic profiles from each of the mounds and were initially interpreted as gas plumes.

\subsection{Video survey and analysis}

From 4 to 7 January 2001, the ROV Victor 6000 was deployed for two exploratory dives along a linear distance of $7500 \mathrm{~m}$. This track targeted mounds of particular interest identified from the bathymetric map and side-scan imagery. A total of $20 \mathrm{~h}$ of video was recorded during two dives (Dive 77-01 and 79-03). Video transects were typically flown at an altitude of 2 to $3 \mathrm{~m}$ over the bottom at a vehicle speed of $0.5 \mathrm{~m} \mathrm{~s}^{-1}$. Victor 6000 used a Posidonia (Ixsea) USBL positioning system for navigation with $1 \%$ of depth accuracy $(<5 \mathrm{~m}$ at this depth).

For habitat interpretation, video footage recorded, using a downward-looking S-VHS camera with a fixed focal length, was analysed. Megafaunal distributions were obtained from processing of both forward- and downward-looking cameras. Some close-ups of the coral communities were also obtained and were useful for taxonomic identification of the megafauna. Post-processing of the dive data was based on ADELIE software, a ArcGIS $®$ based routine (Lecornu, 2000). This extension includes navigation data correction and management of time-synchronisation replay between videotapes and submersible navigation data. Therefore, video data including observation of habitat limits or megafaunal organisms (invertebrates and fish) could be located and mapped along the dive tracks.

Fish were identified to the most accurate taxonomic level and were counted to obtain semiquantitative values of fish abundance and information on habitat selectivity.

The habitat classification previously used for examination of the association of fish species with cold-water coral reefs (Costello et al., 2005; Ross and Quattrini, 2007) was chosen to classify the coral distribution in the surveyed area. The following classes were used: (i) soft sediment, (ii) transitional reef and (iii) dense living coral reef (Fig. 2). The off-reef soft sediment habitat was composed of silty and heavily bioturbated mud, the transitional reef included areas of mostly coral rubble with occasional scattered live corals and/or sponges. The dense living coral reef habitat is a complex three-dimensional habitat formed by living Lophelia pertusa coral colonies (up to $0.4 \mathrm{~m}$ high) settled on dead coral skeletons.

\subsection{Off-reef beam trawl sampling}

A $6 \mathrm{~m}$ wide beam trawl with a 1-cm mesh size was deployed in the vicinity of the coral mounds (Fig. 1b). One haul (CP-09, ZAIANGO BIOL 2 cruise, 2000) was carried out with a 30 min tow duration and an estimated length of $1400 \mathrm{~m}$. Megafauna was immediately sorted on board. Specimens were identified to the species or genus level by taxonomic experts: 
Rudo von Cosel (Museum National d'Histoire Naturelle, France) for molluscs, Nicolas Bailly and Samuel Iglesias (Museum National d'Histoire Naturelle, France) for fish.

\section{Results}

\subsection{Geological setting}

The results from the geophysical survey presented in this study describe the geological structure of the northern part of the Angola margin. Here, the deep Mesozoic salt deposits of the margin crept due to the weight of the overlying Cenozoic sediments and initiated salt rafts. The displacement of these salt rafts along the normal NW-SE trending faults generated secondary N-S faults in the overlying sediment visible on the morpho-structural map (Fig. 3). Although the slope is less than $1^{\circ}$, the horizontal component of gravity was strong enough to generate marine slope instability as already suggested by Sultan (Sultan et al., 2001). This instability controls superficial phenomena such as furrow fields (due to both creep and fluid migration) pockmarks (due to fluid migration) and a buried fractured layer within the lower Cenozoic and Quaternary deposits. This fractured layer can result from a hydrofracturing process caused by former or present seeps (Cartwright, 1994). Elongate-shape coral mounds appear to follow the same NW-SE orientation as the closest normal fault.

\subsection{Coral mound morphology and coral distribution}

The coral field covers a $6 \times 2 \mathrm{~km}$ area parallel to a normal fault and includes five primary mounds and several smaller, rounder isolated reefs. Each mound forms an elongate-shape structure with orientations ranging from $110^{\circ} \mathrm{N}$ to $145^{\circ} \mathrm{N}$. They do not exceed $300 \mathrm{~m}$ in width even when they stretch up to 1 to $1.5 \mathrm{~km}$ in length (Fig. 1). The deep-towed seismic $55^{\circ} \mathrm{N}$ profile crossed two mounds, which are presented in Fig 4. The elevation of these mounds, estimated from seismic data, is about $30 \mathrm{~m}$ and was confirmed by the ROV altimeter data on a transect from the base to the summit at a depth of $340 \mathrm{~m}$ (Fig. 5). Side-scan data is not accurate enough to distinguish living coral from coral debris, but this was observed and mapped using the video transects filmed by the ROV (Fig. 5). Analysis of video footage revealed dense living coral patches (up to $1 \mathrm{~m}^{2}$ each) on the summits of mounds and coral rubble mixed with dead corals (i.e. transitional reef) along the flanks. From visual observations, the transitional reef habitat appeared to be more extensive along southern flanks with dead corals decreasing in density from summit to base. No evidence of trawl damage or other signs of anthropogenic activities was observed.

From bathymetric data, narrow isobaths present on the SW flanks and deeper depressions, ranging from 5 to $10 \mathrm{~m}$, at the base of these flanks both indicated asymmetric mound topography (Fig. 5). Reflector patterns on the SAR seismic profiles suggested two types of structures. First, the seafloor reflector may result from erosion due to currents that create depressions around mounds (Fig $4 \mathrm{~b}$ and $4 \mathrm{c}$ ). Second, at one mound, reflectors gently dipping toward the reef (Fig 4c) suggested a local collapse of the layers that may have been triggered by fluid escape or seepage. The presence of pockmarks and fractured layers in the vicinity is evidence that fluid escapes may occur in the area.

\subsection{Benthic communities}

Samples of the scleractinian reef-building species were identified as Lophelia pertusa Linnaeus, 1758 ( $\mathrm{H}$. Zibrowius, pers. comm.). However, video observations also suggested the presence of Madrepora oculata Linnaeus, 1758. Two successive temperature profiles showed $8.8^{\circ} \mathrm{C}$ at $360 \mathrm{~m}$ deep and $7.7^{\circ} \mathrm{C}$ at $460 \mathrm{~m}$ deep. These values are consistent with the known temperature tolerance of $L$. pertusa (Freiwald, 2002). 
The composition of the associated megafauna was dominated by the sponge Aphrocallistes sp., gorgonians and echinoderms (mainly Echinothuridae). One small size and unbranched antipatharian species, Stylopathes sp., was observed and collected.

The distribution of the ichthyofauna in relation to habitat types is summarised in Table 1 . The analysis included 16 different taxa of which 6 were identified to the genus level and 4 to the species level (Fig. 6). The most striking feature was the presence of an unidentified species belonging to the family Zoarcidae that dominated the fish fauna associated with the dense living corals and with transitional reef habitats. Some individuals were observed hiding on the coral structures, but no feeding behaviour was detected.

To examine habitat selectivity of fish, data from the beam trawl CP-09, carried out on soft sediment around coral mounds, were compared with ROV observations. The estimated track of this trawl (Fig. 1) was located a few hundred metres from living coral colonies. Nevertheless, no fragments of living or dead corals were collected. The trawled fish community was dominated in abundance and biomass by Laemonena laureyensi from the family Moridae and various Macrouridae (four identified species). Although it was the most abundant fish family observed in the video record, Zoarcidae fish, were not found in the beam trawl hauls. Surprisingly, no dorso-ventrally flattened fishes (e.g. Raja sp., Torpedo sp. and Lophiodes sp.) were collected.

The video recording revealed the presence of bivalve shell fields on the sediment around and in depressions between mounds (Fig. 5). Three new species of the family Lucinidae were identified from samples collected by beam trawl CP-09 in the vicinity of coral mounds (Graecina karinae n. sp., Lucinoma myriamae n. sp., Joellina dosiniformis n. sp. (Cosel, 2006)). L. myriamae is the only species collected with the ROV during dives 77-01 and 79-03 (Fig. 7) and came up as agglomerations of dead shells embedded in very sticky, dark grey mud (Fig. $7 b)$, but none of the lucinids were collected alive. Some valves had pieces of solidified mud on them, which were difficult to remove. Reducing sediments covered with bacterial mats were also observed during our surveys (Fig. 7a). In addition, some isolated living coral colonies were observed growing on a substratum of dead lucinid shells at the base of mounds (Fig. 7b).

\section{Discussion}

\subsection{Mound morphology}

The newly described coral mounds from Angola margin colonised by Lophelia pertusa can be compared with their counterparts present along other Atlantic margins (Freiwald, 2002; Freiwald et al., 2004). Three areas have already been well-documented by high-resolution geophysical surveys: the Brazilian margin, the south-eastern margin of the United States, and the north-western margins of Europe, particularly the Norwegian and Irish margins. Situated on the eastern side of the Atlantic Ocean on about the same latitude as the Angola margin, the Brazilian deep-water coral banks-as of yet unexplored by any submersiblecan reach hundreds of metres in length, tens of metres in width, 10 to $15 \mathrm{~m}$ in height and are characterised by a $40 \mathrm{~km}$ long coral field found at between 570 and $850 \mathrm{~m}$ in depth (Viana et al., 1998). Off the United States, a survey carried out in the deep waters of the Straits of Florida revealed the presence of more than 30 coral mounds that are at least $25 \mathrm{~m}$ high and numerous smaller mounds. The tallest mound reaches a height of $90 \mathrm{~m}$ and has a base width of $350 \mathrm{~m}$. The distribution of these mounds follows low-relief ridges that are roughly perpendicular to the strongest bottom current (Grasmueck et al., 2006). In this province, coral mounds are found between 400 and $800 \mathrm{~m}$ in depth. Along the NW European margin, coral mounds are gathered in several carbonate mound provinces extending from Norway to Ireland (Wheeler et al., 2007). Off Ireland, the average height of the Belgica carbonate mounds, one of the best studied provinces, is $200 \mathrm{~m}$ (De Mol et al., 2005) and some mounds have diameters ranging from hundreds of metres to a few kilometres at depths ranging from 
500 and $1000 \mathrm{~m}$. In the majority of these coral mound provinces, there is a clear trend for mounds to be aligned parallel to the continental slope, although perpendicular alignments have also been observed (Wheeler et al., 2007). In comparison with other coral mound provinces, the Angola coral mounds are relatively small in size and may have a narrow bathymetric range. However, results from the morpho-structural interpretation map (Fig. 3) were restricted to the deepest part of the margin. Adjacent areas of this margin should be mapped for a more comprehensive assessment of coral occurrence in the Gulf of Guinea.

The new observations off Angola given here are consistent with the theory that mound morphology is an expression of environmental controls and constraints under which these mounds grow (Wheeler et al., 2007). Here, salt tectonic processes-also frequently involved in seepage-appeared to influence the elongate-shape structure and orientation of the coral mounds. Accordingly, seismic data showed a gentle dip toward the reef (Fig 4c), suggesting a collapse that could be associated with seepage. This hypothesis is also consistent with the presence of reduced sediment at the base of mounds. Unfortunately, the seismic profile, oriented in the same direction as the ridge structure, could not provide explicit enough information. A further perpendicular (i.e. NNE-SSW trending) profile cutting across the structure should be taken in future investigations to provide more explicit information.

In addition, the asymmetric mound topography and depressions around the coral mounds off Angola may be related to currents, where turbulence has given the mounds their shape. Depressions on the steep downslope side of some of the Belgica mounds in the Porcupine Sea Bight, reported to be up to $50 \mathrm{~m}$ deep, are thought to result from strong bottom currents (Van Rooij et al., 2003). Near the Angola coral mounds, at $1300 \mathrm{~m}$ in depth, the bottom currents oscillate mainly along the isobaths, i.e. ca. NNW-SSE trending and the residual current is oriented SSE (Vangriesheim et al., 2005), closely parallel to the reef system. We hypothesise here that a slight shift of a few degrees between the reef system inherited from salt tectonics processes and residual currents may be responsible for the observed mound asymmetry (steeper on downslope side) and depressions.

\subsection{Benthic community associated with corals}

Dominating the sessile megafaunal community of the Angola coral mounds, the "glass sponge" Aphrocallistes sp. is also abundant on Lophelia pertusa reefs off Ireland (Vacelet, pers. com., Le Guilloux et al., unpubl.) and off south-eastern United States (Reed et al., 2006). While antipatharians are an important component of the suspension-feeding fauna in many deep-water coral provinces of the NE Atlantic (Hall-Spencer et al., 2007), the exploration at the Angola mounds only revealed one coral species, Stylopathes sp. and observations were rare.

This is the first report of Zoarcidae fish on a Lophelia reef, although some Lycodes spp. have already been collected on deep-sea banks colonised by solitary corals off North Carolina (George, 2002). However, Zoarcidae fish are common in cold-seep environments, and were observed in an active "pockmark" area deeper on the Angola margin (Olu-Le Roy et al., 2007). Their high abundances observed in the living and dead coral framework, their absence in the surrounding sediments, and observed hiding behaviour suggests potential habitat selectivity, which has never been described before for this family of fish. Although differences between visual observations and trawl captures are mainly influenced by the spatial distribution of fish (Trenkel et al., 2004), their absence in the beam trawl in the vicinity of the coral mounds may also indicate that the species could select the coral habitat. The observation of two different species from the order Lophiiformes (Chaunax pictus and Lophiodes sp.), both predator species inhabiting the transitional reef habitat, is congruous with other deep-sea coral provinces. Species of the genera Chaunax and Lophiodes were recently documented in $L$. pertusa reefs off south-eastern United States (Caruso et al., 2007) and Lophius piscatorius is also known from NE Atlantic $L$. pertusa reefs (Costello et al., 2005; Le Guilloux et al., unpubl.). Helicolenus dactylopterus and Gephyroberyx darwini or counterparts of their respective families (i.e. Sebastidae and Trachichthyidae) have already been frequently observed in association with deep-sea corals from both sides of the North 
Atlantic Ocean (Costello et al., 2005; Ross and Quattrini, 2007; Le Guilloux et al., unpubl.). However, these species with large range distributions are suspected to have ubiquitous behaviour not restricted to complex biogenic structures (Auster, 2005). Raja sp. and Torpedo sp. seem to be rare species even on the video record and the limited trawl effort could explain their absence in the trawl captures. However, these predators may be attracted to the reef to prospect for benthic prey. Five different species of the family Macrouridae were identified in the trawls, compared to only two from visual observations on the reef. Identification of Macrouridae is generally based on microscopic criteria and the number of species observed on video is probably underestimated. In this case, a preference for the coral habitat of these species is questionable. Nevertheless, differences in habitat use for species of Macrouridae and even for a single genus (i.e. Nezumia spp.) was demonstrated by Ross and Quattrini (2007), based on a study including 99 species of fish observed and collected on deep-coral banks off south-eastern United States. For the other rare species captured or observed, habitat use and spatial distribution cannot be discussed here because of biases in identification related to small size (Ogcocephalidae), confusing shape (Anguillifomes) or effective camouflage (Soleidae).

\subsection{Origin of the mounds?}

The lucinids, observed at the base of the coral mounds and sampled as empty shells by trawls, were mostly encountered in littoral sulphide-rich sediments and at the shallowest seep sites, such as in the North Sea, or down to $2000 \mathrm{~m}$ in the Eastern Mediterranean Sea (Dando et al., 1994; Olu-Le Roy et al., 2004). Although lucinid species are able to feed on particles, a large part of their nutrition is derived from endosymbiotic bacteria (Taylor and Glover, 2000). In addition, they display anatomical characteristics typical of symbiontassociated bivalves, such as a reduced gut and large fleshy gills with symbiotic bacteria found in specialized epithelial cells (Duperron et al., 2006). Moreover, reducing sediment covered by bacterial mats, typically encountered at hydrocarbon or methane cold-seeps, was observed during our surveys (Fig. 7a). The sulphide-oxidizing filamentous bacteria that generally form these mats are also indicative of sulphide-rich environment (CambonBonavita et al., this issue). Therefore, the reducing sediments that characterize the closed environment of the coral mounds could be related to methane or higher hydrocarbon fluid seepages that commonly occur along the whole margin (Sibuet et al., 2002). Furthermore, the geological setting which is dominated by the salt tectonics in the area and the occurrence of several features related to fluid expulsion ((Fig. 3), suggest the possibility of fluid escape in the vicinity of the coral mounds.

Nevertheless, the nutritional link between chemoautotrophic production by seeps and $L$. pertusa, as previously suggested for Norwegian corals (Hovland et al., 1998), has been refuted by carbon isotope studies of coral polyps from our study area that reported values typical of photosynthesis-based nutrition $\left(\delta{ }^{13} \mathrm{C}=-18.9 \%\right.$ ). These values are consistent with previously published data for other NE Atlantic L. pertusa reefs (Duineveld et al., 2004). Furthermore, no species typical of cold seeps were observed on the mounds themselves. Nevertheless, substrata composed of dead shells and solidified mud (Fig. 7b) or of methanederived authigenic carbonates (Aloisi et al., 2000; Ritger et al., 1987) from a previously active seep, or, alternatively, low seepages over a long time period could have acted as an initial stage for coral reef development, by providing a hard, carbonate substratum induced by biomineralisation processes. Some isolated living coral colonies were indeed observed growing on a dead lucinid shell field. The influence of the hypothesized processes related to fluid in the formation of carbonates may be further resolved by sedimentological studies and deep coring, to identify the initial substrata on which the coral first settled. The existence of an initial phase of hydrocarbon seepage was also suggested in a Pliocene deep-water coral limestone in Italian waters by the negative stable-carbon isotope composition of the limestone and the occurrence of chemosynthetic infaunal lucinid bivalves (Taviani et al., 2005). 
In some cases, gross mound morphology is "inherited" from the morphology of the geological structures that were colonised because they offered suitable substrates or topographically elevated settings favourable to the growth of Lophelia (Wheeler et al., 2007). On the NW European margin, this theory is especially based on the observation of ridge-shaped coral mounds that are influenced by the morphology of morainic ridges (Freiwald et al., 1999) and pockmarks (Masson et al., 2003). In our case, the elongate-shape of the coral mounds could be linked to the underlying faults (Figs. 3 and 4) and the coral developed on these elevated topographic features initiated by tectonic processes. This scenario supports a modified version of the gas-seep hypothesis for mound formation (Hovland et al., 1998). Finally, occurrence of corals on geological structures that have been formed by fluid or gas emissions could be a widespread phenomenon along continental margins. Along the Brazilian coast, the distribution of coral mounds at the edge of pockmarks seems to be closely related to turbulence and eddies that may increase the concentration of food particles. Moreover, co-occurrence of seeps and coral communities is suggested by dredge captures that include high densities of an undescribed Amelinna species, belonging to the polychaete subfamily Melinninae, commonly found in reducing habitats (Sumida et al., 2004). Reefs have also been observed growing on seep-derived carbonates in the Gulf of Mexico but without any trophic links (Cordes et al., 2008). The co-existence of coral-rich carbonate build-ups and mud volcanic activity was confirmed in the Gulf of Cadiz, although restricted to the shallower Spanish and Moroccan sectors (Pinheiro et al., 2003). According to these authors, the presence of a hard substrate in some of the mud volcanoes, namely the existence of carbonate crusts or mud breccias, may be crucial to the initial settlement of coral larvae. Finally, off Mauritania (Colman et al., 2005), evidence suggests that the corals on the present-day mound system may rely on hydrographic conditions for their survival, but the authors do not discount the possibility that hydrocarbon seepage was an initial factor in promoting the formation of carbonate mounds.

However, a second hypothesis is proposed to explain the presence of reduced sediment around the Angola coral reefs. The erosional processes identified in the present study may be able to create depressions around the mounds. If hydrodynamic regimes were variable in time, these depressions could accumulate a large amount of particulate matter that subsequently degrades and generates reduced conditions (sulphide-rich sediments). These conditions would favour the establishment of specialised fauna (lucinids) without seepage, as in shallow-water systems. Global distribution patterns of the estimated flux of particulate organic carbon to the seafloor (Seiter et al., 2005) identify the Angola margin as a rich area with flux values of one order of magnitude higher than the European continental margins. This organic matter supply likely supports the reef community through the detritical food chain.

\section{Conclusion}

This study represents the first report of in situ observation of Lophelia pertusa reefs in the South-East Atlantic and confirms the widespread distribution of this reef-forming species in the Atlantic Ocean. Our observations of coral reefs in an environment that could be, or that could have been, influenced by seeps, supports that coral communities may have been favoured by environmental features initiated by cold seepages. Drilling the mounds would give some arguments to support this hypothesis or not. Semi-quantitative data on fish abundance and comparison with off-reef beam trawl capture gave a first insight into the fish community associated with this bathyal coral reef ecosystem. No observation of trawl damage or other signs of anthropogenic activities were identified from this study. However, potential high-value target fish species were observed in this exceptional pristine environment. Since this study was carried out, Angola fisheries policy supports increased fishing efforts for demersal fish, but fisheries' impact on deep-sea corals has apparently never been addressed. 


\section{Acknowledgements}

We are grateful to our colleagues of Ifremer, particularly J.Galéron et M-C.Fabri, and to the pilots of ROV Victor 6000 and the crews of R/V L'Atalante for assisting in the data collection during the cruise BIOZAIRE 1 (chief scientist M. Sibuet). We are deeply indebted to R. von Cosel for mollusc identification, $\mathrm{H}$. Zibrowius for identification of scleractinians, and Tina Molodtsova for identification of antipatharians. We thank K.Dekindt and A.Fifis, for their contribution to video and sample analysis. We thank B. Savoye (IFREMER) and A. Morash (Total) who provided geophysical data from the ZAIANGO programme. We are grateful to J.Desneulin (Total) who has initiated this study by providing the first samples and bathymetric maps to Ifremer. We also thank anonymous reviewers for their constructive comments and English language editing. The BIOZAIRE program was supported by Ifremer and Total. E. Le Guilloux's PhD is supported by IFREMER and the Brittany Regional Council.

\section{References}

Aloisi, G., Pierre, C., Rouchy, J.-M., Foucher, J.-P., Woodside, J., Party, T.M.S., 2000. Methane-related authigenic carbonates of eastern Mediterranean Sea mud volcanoes and their possible relation to gas hydrate destabilisation. Earth and Planetary Science Letters 184, 321-338.

Antoine, D., André, J.-M., Morel, A., 1996. Oceanic primary production 2. Estimation at global scale from satellite (coastal color scanner) chlorophyll. Global Biogeochemical Cycles 10, $57-$ 69.

Auster, J., 2005. Are deep-water corals important habitats for fishes? In: Freiwald, A., Roberts, M. (Eds.), Cold-Water Corals and Ecosystems. Springer, pp. 747-760.

Behrenfeld, M.J., Falkowski, P.G., 1997. Photosynthetic rates derived from satellite-based chlorophyll concentration. Limnology and Oceanography 42, 1-20.

Brun, J.-P., Fort, X., 2004. Compressional salt tectonics (Angolan margin). Tectonophysics $382(3-4), 129-150$.

Cartwright, J.A., 1994. Episodic basin-wide fluid expulsion from geopressured shale sequences in the North-Sea Basin. Geology 22 (5), 447-450.

Caruso, J.H., Ross, S.W., Sulak, K.J., Sedberry, G.R., 2007. Deep-water chaunacid and lophiid anglerfishes (Pisces: Lophiiformes) off the south-eastern United States. Journal of Fish Biology 70 (4), 1015-1026.

Colman, J., Gordon, D., Lane, A., Forde, M., Fitzpatrick, J., 2005. Carbonate mounds off Mauritania, Northwest Africa: status of deep-water corals and implications for management of fishing and oil exploration activities. Cold-Water Corals and Ecosystems, pp. 417-441.

Cordes, E.E., McGinley, M.P., Podowski, E.L., Becker, E.L., Lessard-Pilon, S., Viada, S.T., Fisher, C.R., 2008. Coral communities of the deep Gulf of Mexico. Deep Sea Research Part I: Oceanographic Research Papers 55 (6), 777-787.

Cosel, R.V., 2006. Taxonomy of tropical West African bivalves. VI. Remarks on Lucinidae (Mollusca, Bivalvia), with description of six new genera and eight new species. Zoosystema 28 (4), 805-851.

Costello, M.J., McCrea, M., Freiwald, A., Lundälv, T., Jonsson, L., Bett, B.J., Van Weering, T.C.E., de Haas, H., Roberts, J.M., Allen, D., 2005. Role of cold water Lophelia pertusa coral reefs as fish habitat in the NE Atlantic. In: Freiwald A, R.J. (Ed.), Cold water corals and ecosystems. Springer-Verlag Berlin Heidelberg, pp. 771-805.

Dando, P.R., Ridgway, S.A., Spiro, B., 1994. Sulphide "mining" by lucinid bivalve molluscs: demonstrated by stable sulphur isotope measurements and experimental models. Marine Ecology Progress Series 107, 169-175. 
De Mol, B., Henriet, J.P., Canals, M., 2005. Development of corals banks in Porcupine SeaBight: do they have Mediterranean ancestors? In: Freiwald A, R.J. (Ed.), Cold-Water Corals and Ecosystems. Springer, pp. 516-533.

Duineveld, G.C.A., Lavaleye, M.S.S., M., B.E., 2004. Particle flux and food supply to a seamount cold-water coral community (Galicia Bank, NW Spain). Marine Ecology Progress Series 227, 13-23.

Duperron, S., Fiala-Médioni, A., Caprais, J.C., Olu, K., Sibuet, M., 2006. Evidence for chemoautotrophic symbiosis in a Mediterranean cold seep clam (Bivalvia: Lucinidae): comparative sequence analysis of bacterial 16S rRNA, APS reductase and RubisCO genes. FEMS Microbiology Ecology 59 64-70.

Duval, B., Cramez, C., Jackson, M.P.A., 1992. Raft tectonics in the Kwanza Basin, Angola. Marine and Petroleum Geology 9 (4), 389-404.

Freiwald, A., 2002. Reef-forming cold-water corals. In: Ocean Margin Systems. G Wefer, D.B., D Hebbeln, BB Jorgensen, M Schluter, TCE van Weering (Ed.). Springer, Heidelberg, pp. 365-385.

Freiwald, A., Fossa, J.H., Grehan, A., Koslow, J.A., Roberts, J.M., 2004. Cold-water coral reefs. UNEP-WCMC, Cambridge, UK.

Freiwald, A., Wilson, J.B., Henrich, R., 1999. Grounding Pleistocene icebergs shape recent deep-water coral reefs. Sedimentary Geology 125 (1-2), 1-8.

George, R.Y., 2002. Ben Franklin temperate reef and deep sea 'Agassiz Coral Hills' in the Blake Plateau off North Carolina. Hydrobiologia 471, 71-81.

Grasmueck, M., Eberli, G.P., Viggiano, D.A., Correa, T., Rathwell, G., Luo, J., 2006. Autonomous underwater vehicle (AUV) mapping reveals coral mound distribution, morphology, and oceanography in deep water of the Straits of Florida. Geophysical Research Letters 33, 1-6.

Hall-Spencer, J., Rogers, A., Davies, J., Foggo, A., 2007. Deep-sea coral distribution on seamounts, oceanic islands, and continental slopes in the Northeast Atlantic. In: George, R.Y., Cairns, S.D. (Eds.), Conservation and Adaptive Management of Seamount and DeepSea Coral Ecosystems. Univ Miami, Miami, pp. 135-146.

Henriet, J.P., De Mol, B., Pillen, S., Vanneste, M., Van Rooij, D., Versteeg, W., Croker, P.F., Shannon, P.M., Unnithan, V., Bouriak, S., Chachkine, P., Belgica 97 Shipboard, P., 1998. Gas hydrate crystals may help build reefs. Nature 391 (6668), 648.

Hovland, M., Mortensen, P.B., Brattegard, T., Strass, P., Rokoengen, K., 1998. Ahermatypic coral banks off Mid-Norway: evidence for a link with seepage of light hydrocarbons. Palaios 13, 189-200.

Jensen, A., Frederiksen, R., 1992. The fauna associated with the bank-forming deepwater coral Lophelia pertusa (Scleractinaria) on the Faroe shelf. Sarsia. 77 (1), 53-69.

Kitahara, M.V., 2007. Species richness and distribution of azooxanthellate Scleractinia in Brazil. Bulletin of Marine Science 81, 497-518.

Lecornu, 2000. ADELIE: Underwater vehicle data post-processing tools. User guide-v. 1.4. IFREMER/DNIS/ESI/DLE/DTI/99-036.

Masson, D.G., Bett, B.J., Billett, D.S.M., Jacobs, C.L., Wheeler, A.J., Wynn, R.B., 2003. The origin of deep-water, coral-topped mounds in the northern Rockall Trough, Northeast Atlantic. Marine Geology 194 (3-4), 159.

Nouzé, H., Sibuet, J.-C., Savoye, B., Marsset, B., Thomas, Y., 1997. Pasisar: Performances of a high and very high resolution hybrid deep-towed seismic device. Marine Geophysical Researches 19 (5), 379-395.

Olu-Le Roy, K., Caprais, J.C., Fifis , A., Fabri , M.C., Galéron, J., Budzinski, H., Le Ménach, K., Khripounoff, A., Ondréas, H., Sibuet, M., 2007. Cold seep assemblages on a giant pockmark off West Africa: spatial patterns and environmental control. Marine Ecology 28, 115-130.

Olu-Le Roy, K., Sibuet, M., Fiala-Médioni, A., Gofas, S., Salas, C., Mariotti, A., Foucher, J.P., Woodside, J., 2004. Cold seep communities in the deep eastern Mediterranean Sea: composition, symbiosis and spatial distribution on mud volcanoes. Deep-Sea Research I 51, 1915-1936. 
Passeri Lavrado, H., Lage Ignacio, B. (Ed.), 2006. Biodiversidade bentônica da costa central da Zona Econômica Exclusiva Brasileira, Rio de Janeiro.

Pinheiro, L.M., Ivanov, M.K., Sautkin, A., Akhmanov, G., Magalhaes, V.H., Volkonskaya, A., Monteiro, J.H., Somoza, L., Gardner, J., Hamouni, N., Cunha, M.R., 2003. Mud volcanism in the Gulf of Cadiz: results from the TTR-10 cruise. Marine Geology 195 (1-4), 131-151.

Pires, D.D., 2007. The azooxanthellate coral fauna of Brazil. In: George, R.Y., Cairns, S.D. (Eds.), Conservation and Adaptive Management of Seamount and Deep-Sea Coral Ecosystems. Univ Miami, Miami, pp. 265-272.

Reed, J.K., Weaver, D.C., Pomponi, S.A., 2006. Habitat and fauna of deep-water Lophelia pertusa coral reefs off the southeastern U.S.: Blake plateau, Straits of Florida, and Gulf of Mexico. Bulletin of Marine Science 78, 343-375.

Ritger, S.D., Carson, B., Suess, E., 1987. Methane-derived authigenic carbonates formed by subduction-induced pore-water expulsion along the Oregon/Washington margin. Geological Society of American Bulletin 98, 147-156.

Rogers, A.D., 1999. The biology of Lophelia pertusa (Linnaeus 1758) and other deep-water reef-forming corals and impacts from human activities. International Review of hydrobiology 84 (4), 315-406.

Ross, S.W., Quattrini, A.M., 2007. The fish fauna associated with deep coral banks off the southeastern United States. Deep-Sea Research I 54, 975-1007.

Rouby, D., Raillard, S., Guillocheau, F., Bouroullec, R., Nalpas, T., 2002. Kinematics of a growth fault/raft system on the West African margin using 3-D restoration. Journal of Structural Geology 24 (4), 783-796.

Savoye, B., Cochonat, P., Apprioual, R., Bain, O., Baltzer, A., Bellec, V., Beuzart, P., Bourillet, J., Cagna, R., Cremer, M., Crusson, A., Dennielou, B., Diebler, D., Droz, L., Ennes, J., Floch, G., Foucher, J., Guiomar, M., Harmegnies, F., Kerbrat, R., Klein, B., Khun, H., Landure, J., Lasnier, C., Le Drezen, E., Le Formal, J., Lopez, M., Loubrieu, B., Marsset, T., Migeon, S., Normand, A., Nouze, H., Ondreas, H., Pelleau, P., Saget, P., Seranne, M., Sibuet, J.C., Tofani, R., Voisset, M., 2000. Structure et évolution récente de l'éventail turbiditique du Zaïre: Premier résultats scientifiques des missions d'exploration ZaiAngo 1 and 2 (Marge Congo-Angola). Comptes Rendus de l'Académie des Sciences de Paris, Géologie Marine 311, 211-220.

Seiter, K., Hensen, C., Zabel, M., 2005. Benthic carbon mineralization on a global scale. Global Biogeochemical Cycles 19.

Sibuet, M., Olu-Le Roy, K., 2002. Cold Seep Communities on Continental Margins: Structure and Quantitative Distribution Relative to Geological and Fluid Venting Patterns. In: G. Wefer, D.B., D. Hebbeln, B.B. Jorgensen, T. Van Weering (Ed.), Ocean Margin Systems. Springer Verlag, Berlin, pp. 235-251.

Sultan, N., Cochonat, P., Bourillet, J.F., Cayocca, F., 2001. Evaluation of the risk of marine slope instability: A pseudo-3D approach for application to large areas. Marine Georesources \& Geotechnology 19 (2), 107-133.

Sumida, P.Y.G., Yoshinaga, M.Y., Madureira, L.A.S.-P., Hovland, M., 2004. Seabed pockmarks associated with deepwater corals off SE Brazilian continental slope, Santos Basin. Marine Geology 207 (1-4), 159.

Taviani, M., Cavagna, S., Clari, P., Dela Pierre, F., Lopez Correa, M., 2005. Pliocene deepwater coral limestones from the NW Apennines (Italy) and their links to hydrocarbon seepage. Third International Symposium on Deep-Sea Corals, Miami.

Taylor, J.D., Glover, E.A., 2000. Functional anatomy, chemosymbiosis and evolution of the Lucinidae. In: Harper, E.M., Taylor, J.D., Crame, J.A. (Eds.), Evolutionary Biology of the Bivalvia. Geological Soc Publishing House, Bath, pp. 207-225.

Trenkel, V.M., Chris Francis, R.I.C., Lorance, P., Mahévas, S., Rochet, M.J., Tracey, D.M., 2004. Availability of deep-water fish to trawling and visual observation from a remotely operated vehicle (ROV). Marine Ecology Progress Series 284, 293-303.

van Bennekom, A.J., Berger, G.W., 1984. Hydrography and silica budget of the Angola budget. Netherlands Journal of Sea Research 17, 149-200. 
Van Rooij, D., De Mol, B., Huvenne, V., Ivanov, M., Henriet, J.-P., 2003. Seismic evidence of current-controlled sedimentation in the Belgica mound province, upper Porcupine slope, southwest of Ireland. Marine Geology 195 (1-4), 31-53.

Vangriesheim, A., Marie Treguier, A., Andre, G., 2005. Biweekly current oscillations on the continental slope of the Gulf of Guinea. Deep Sea Research Part I: Oceanographic Research Papers 52 (11), 2168-2183.

Viana, A.R., Faugeres, J.C., Kowsmann, R.O., Lima, J.A.M., Caddah, L.F.G., Rizzo, J.G., 1998. Hydrology, morphology and sedimentology of the Campos continental margin, offshore Brazil. Sedimentary Geology 115 (1-4), 133-157.

Wheeler, A.J., Beyer, A., Freiwald, A., de Haas, H., Huvenne, V.A.I., Kozachenko, M., Olu-Le Roy, K., Opderbecke, J., 2007. Morphology and environment of cold-water coral carbonate mounds on the NW European margin. International Journal of Earth Sciences 96 (1), 37-56.

Zibrowius, H., 1980. Les scléractiniaires de la Méditerranée et de l'Atlantique nord-oriental. Memoire de l'institut océanographique 11, 247pp.

Zibrowius, H., Gili, J.M., 1990. Deep-water Scleractinia (Cnidaria:Anthozoa) from Namibia, South Africa, and Walvis Ridge, southeastern Atlantic. Scientia Marina 54, $19-46$.

\section{Table}

Table 1: Fish observed on ROV video footage in the three habitats of Lophelia pertusa reefs. Abundance scored as $+=1-10$ and $++=>10$. Species names in bold were observed only in the coral reef habitat (dense living corals and transitional reef).

\begin{tabular}{|c|c|c|c|c|}
\hline Taxa & & $\begin{array}{c}\text { Dense living } \\
\text { Coral reef }\end{array}$ & $\begin{array}{c}\text { Transitional } \\
\text { reef }\end{array}$ & Off reef \\
\hline Zoarcidae & Undetermined Zoarcidae & ++ & ++ & \\
\hline \multirow[t]{2}{*}{ Macrouridae } & Malacocephalus sp. & ++ & + & \\
\hline & Undetermined & & & ++ \\
\hline Anguilliforme & & + & + & + \\
\hline Synaphobranchidae & & ++ & ++ & ++ \\
\hline Scorpaenidae & Helicolenus dactylopterus & + & & \\
\hline Chaunacidae & Chaunax pictus & & ++ & \\
\hline \multirow[t]{2}{*}{ Ogcocephalidae } & Halieutaea sp. & & ++ & + \\
\hline & Undermined Ogcocephalidae & & + & \\
\hline Lophiidae & Lophiodes sp. & & ++ & \\
\hline Trachichthyidae & Gephyroberyx darwini & & + & \\
\hline Moridae & Laemonema laureysi & & & ++ \\
\hline Zeidae & Zenopsis conchifera & & & + \\
\hline Soleidae & Undetermined & & & + \\
\hline Rajidae & Raja sp. & + & + & \\
\hline Torpedinidae & Torpedo sp. & + & & \\
\hline
\end{tabular}




\section{Figures}

Figure 1: a) Location of the study area (ZB) along the Angola margin. b) SAR deep-towed side-scan sonar mosaic. The solid line represents the location of the selected deep-towed seismic profile and the dotted line shows the location of beam trawl haul CP-09. 


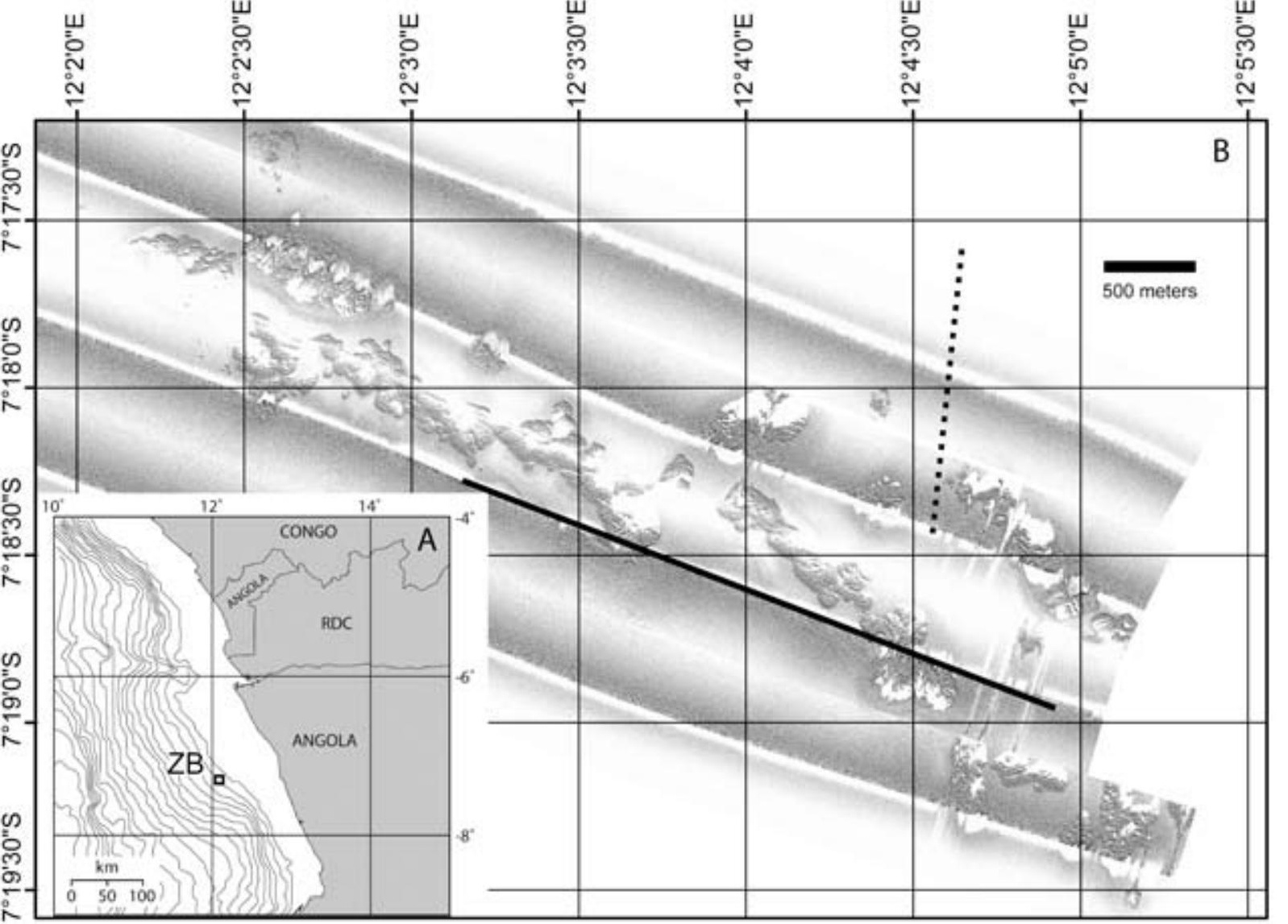


Figure 2: Examples of the three habitat types from video captures: soft sediment (left), transitional zone (middle) and dense living coral or reef (right). 


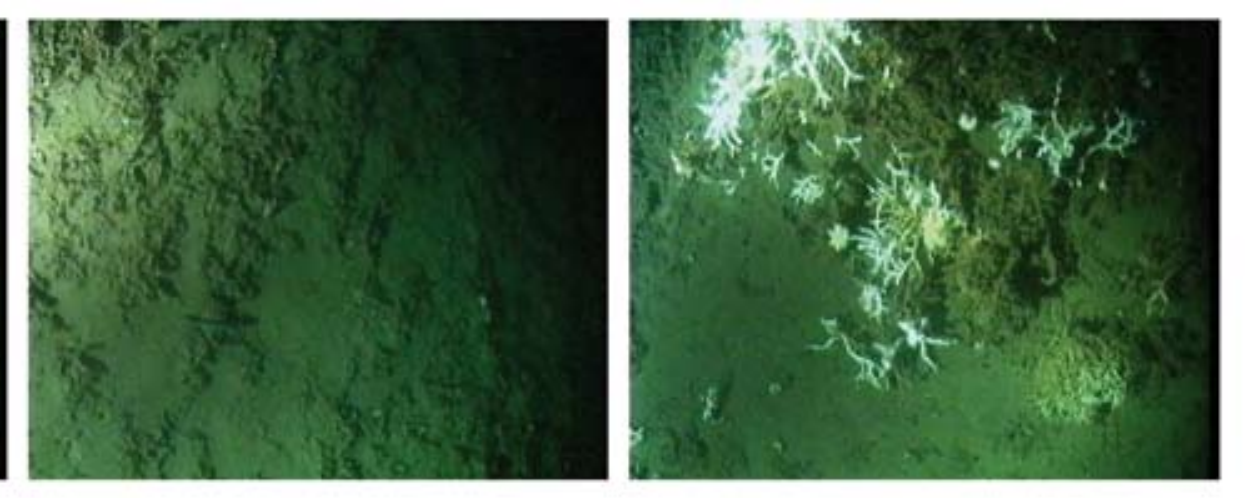


Figure 3: Morpho-structural interpretation map from the Angolan margin, (modified from Savoye et al., unpublished): 1 Faults, 2 furrows, 3 pockmarks, 4 coral mounds, 5 buried fractured layer were interpreted from EM12D and EM300 multibeam echosounders, SAR sub-bottom-profiler and deep-towed side-scan sonar. 
Figure 4: Section across the reef area of the Angolan margin. A) Deep-towed seismic profile. See location in Fig. 1. B) and C) Interpretation. Seismic interpretation (red lines) shows an erosional seafloor reflector $(B$ and $C)$ and internal reflectors which are either gently stretched in the vicinity of a reef $(B)$ or clearly dipping across a reef $(C)$. 


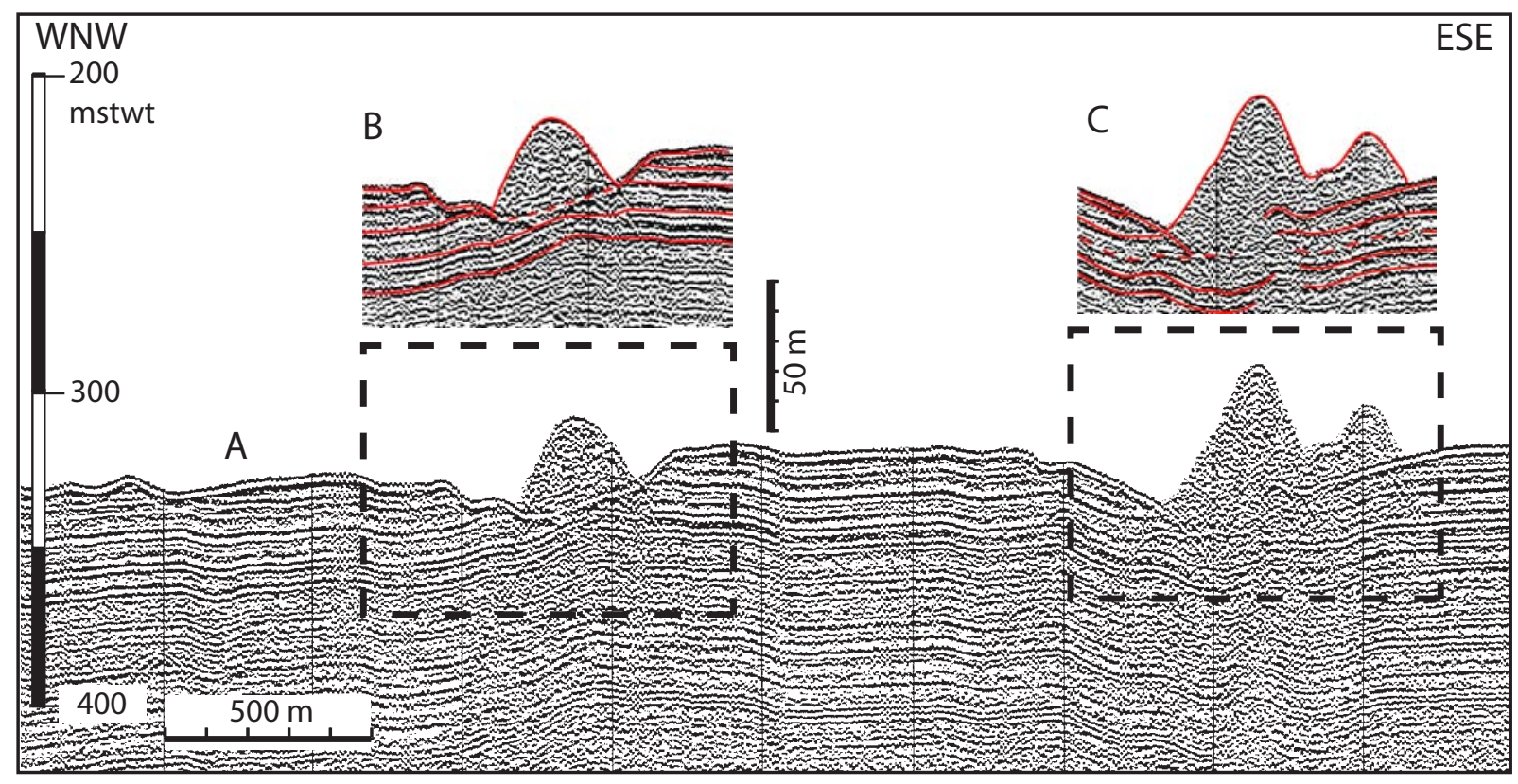


Figure 5: Habitat interpretation map from video survey (dive 77-01 and 79-03 BIOZAIRE cruise, 2001) with distribution of 1) soft sediment, 2) transitional zone, 3) dense living coral reef habitat. Stars represent the location of lucinid shells associated with reduced sediment. Bathymetry was determined from a EM12 multibeam echosounder and side-scan sonar mosaic from the SAR acoustic system (ZAIANGO-SAR cruise, 2000). 


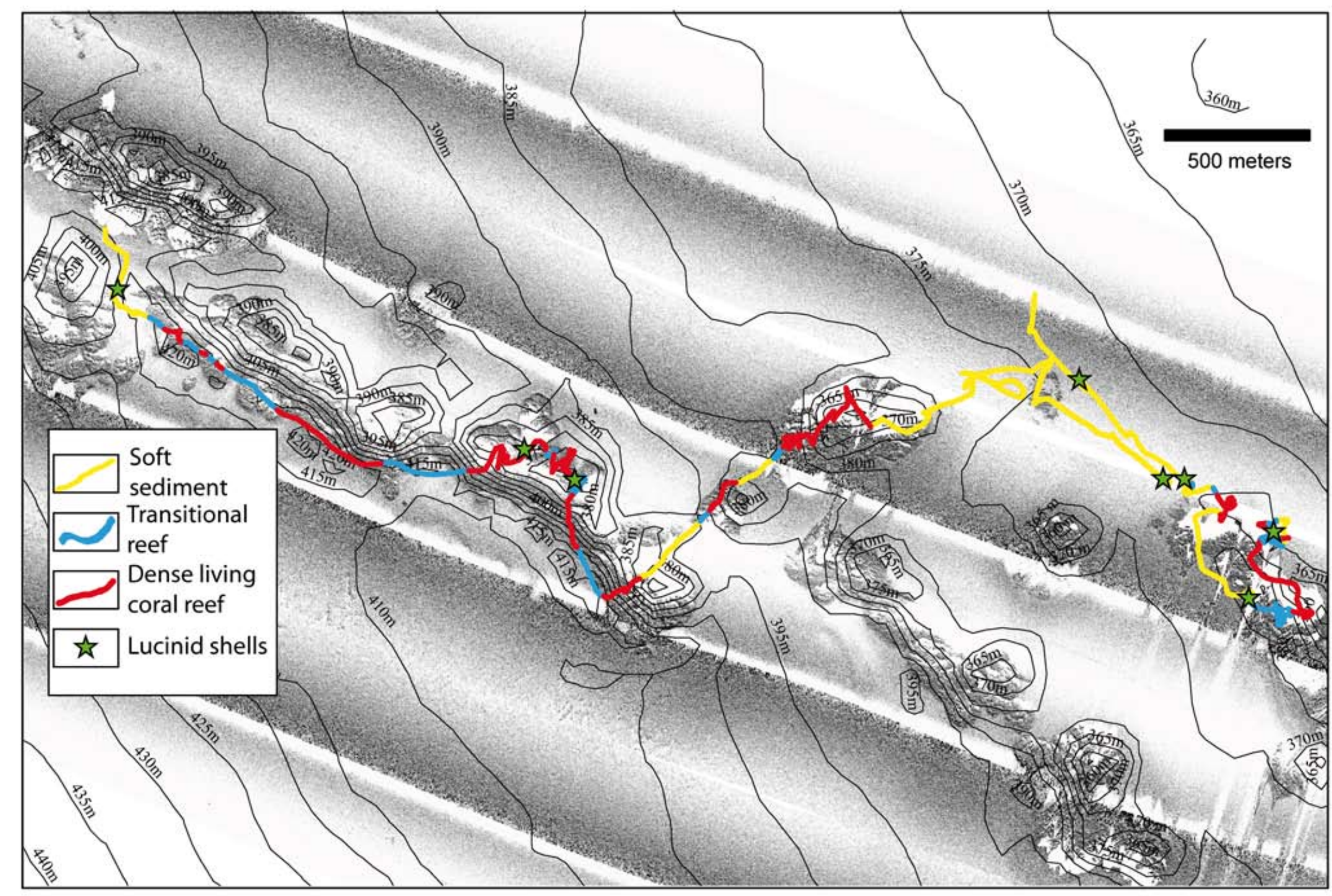


Figure 6: In situ photographs of fish observed during dives 77 and 79, (BIOZAIRE cruise 2001): a) Chaunax sp., b) unidentified Zoarcidae, c) Lophius sp., d) Laemonema laureysi, e) Malacocephalus sp., f) Raja sp., g) Helicolenus dactylopterus, h) Gephyroberyx darwini. 


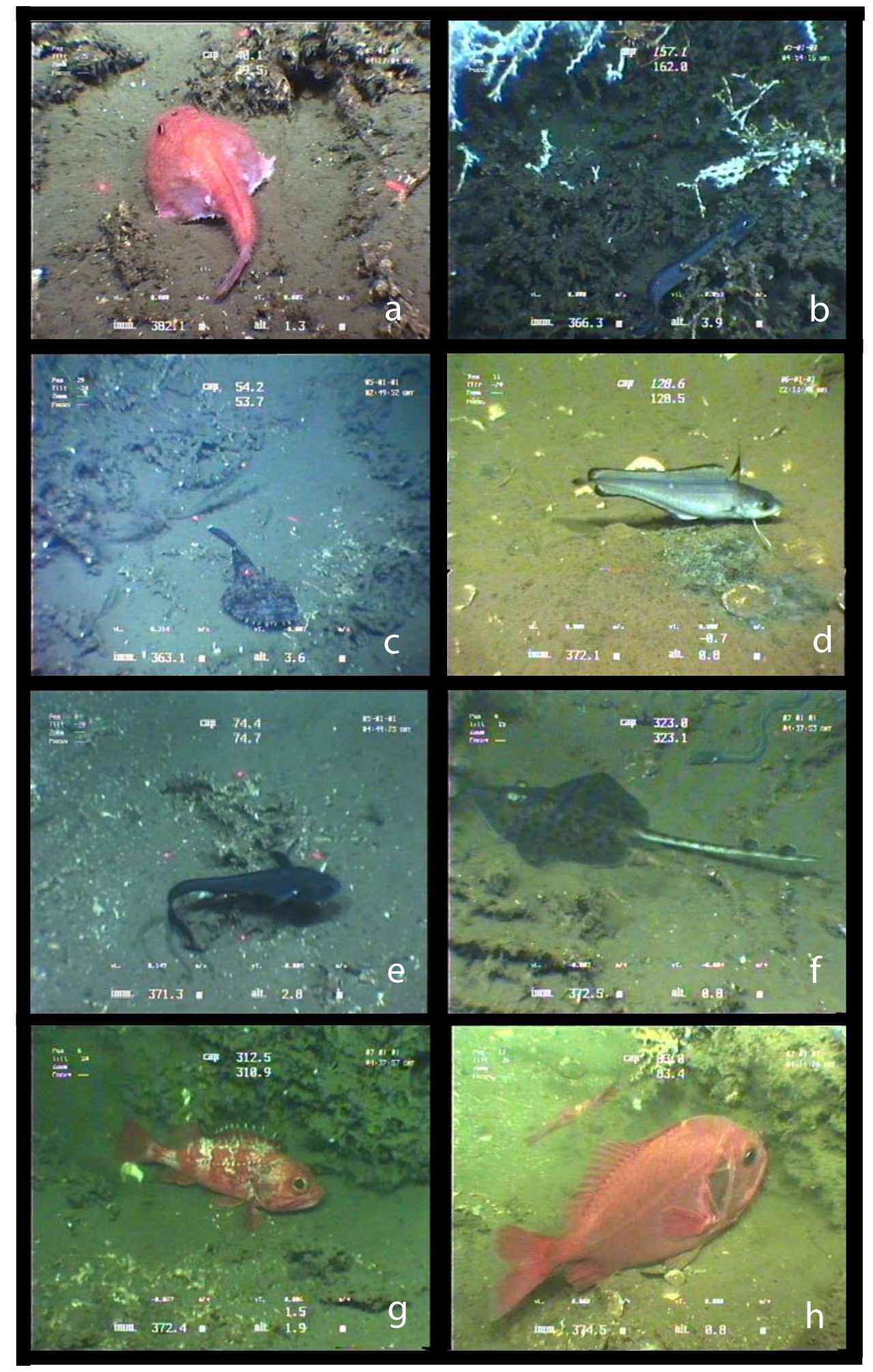


Figure 7: In situ photographs of a) A reduced sediment patch in the vicinity of a coral mound with lucinid shells. b) Mixed lucinid shells and coral debris. c) Lucinoma myriamae Cosel 2007, a new species discovered in a blade core taken during dive 79-03 at the base of a coral mound. 

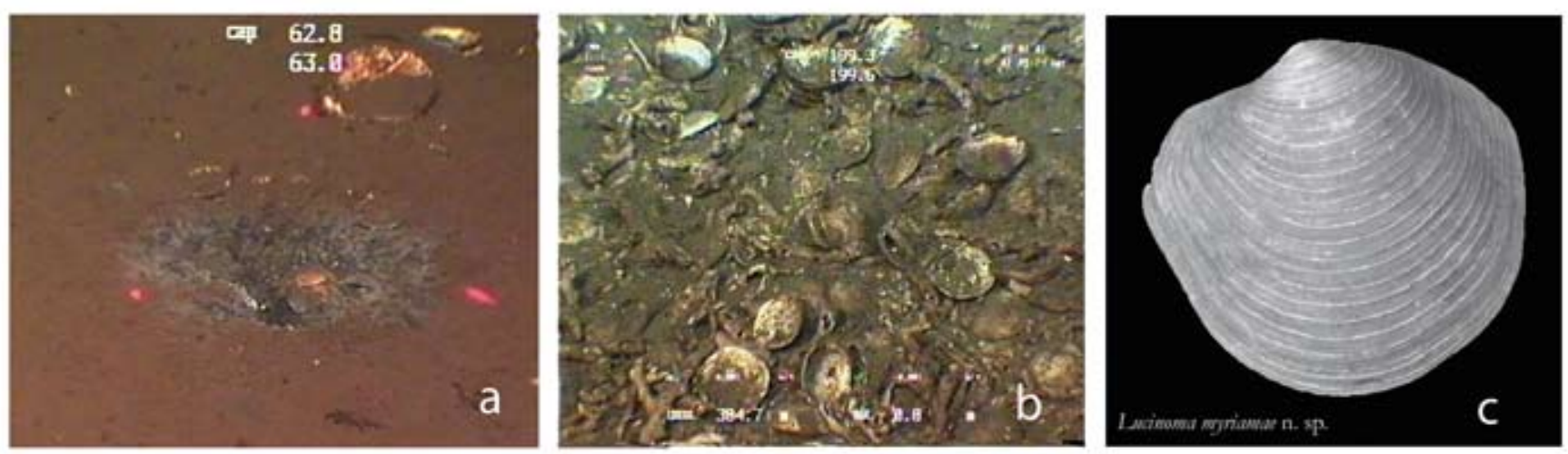